IZA DP No. 4581

The Distributional Impact of In Kind Public Benefits in European Countries

Alari Paulus

Holly Sutherland

Panos Tsakloglou

November 2009 


\title{
The Distributional Impact of In Kind Public Benefits in European Countries
}

\author{
Alari Paulus \\ ISER, University of Essex \\ Holly Sutherland \\ ISER, University of Essex \\ Panos Tsakloglou \\ Athens University of Economics and Business \\ and IZA
}

\author{
Discussion Paper No. 4581 \\ November 2009
}

\author{
IZA \\ P.O. Box 7240 \\ 53072 Bonn \\ Germany \\ Phone: +49-228-3894-0 \\ Fax: +49-228-3894-180 \\ E-mail: iza@iza.org
}

\begin{abstract}
Any opinions expressed here are those of the author(s) and not those of IZA. Research published in this series may include views on policy, but the institute itself takes no institutional policy positions.

The Institute for the Study of Labor (IZA) in Bonn is a local and virtual international research center and a place of communication between science, politics and business. IZA is an independent nonprofit organization supported by Deutsche Post Foundation. The center is associated with the University of Bonn and offers a stimulating research environment through its international network, workshops and conferences, data service, project support, research visits and doctoral program. IZA engages in (i) original and internationally competitive research in all fields of labor economics, (ii) development of policy concepts, and (iii) dissemination of research results and concepts to the interested public.
\end{abstract}

IZA Discussion Papers often represent preliminary work and are circulated to encourage discussion. Citation of such a paper should account for its provisional character. A revised version may be available directly from the author. 
IZA Discussion Paper No. 4581

November 2009

\section{ABSTRACT \\ The Distributional Impact of In Kind Public Benefits in European Countries*}

International comparisons of inequality based on measures of disposable income may not be valid if the size and incidence of publicly-provided in kind benefits differ across the countries considered. The benefits that are financed by taxation in one country may need to be purchased out of disposable income in another. We estimate the size and incidence of in kind or "non cash" benefits from public housing subsidies, education and health care for five European countries using comparable methods and data. Inequality in the augmented income measure is dramatically lower than in disposable income, with the effects of the three components varying in importance across countries. Adapting equivalence scales to take proper account of differences in needs for health care and education across population members reduces the scale of the effect, but does not eliminate it.

JEL Classification: $\quad 138$

Keywords: inequality, in kind transfers, cross-national comparisons

Corresponding author:

Panos Tsakloglou

Department of International and European Economic Studies

Athens University of Economics and Business

76 Patission Street

Athens 10434

Greece

E-mail: panos@aueb.gr

\footnotetext{
* The analysis on which this paper is based was carried out as part of the AIM-AP project which was funded by the European Commission Framework Programme 6, 2006-09 under Priority 7 Citizens and Governance in a Knowledge-based Society [Project no. 028412]. AIM-AP stands for "Accurate Income Measurement for the Assessment of Public Policies" and estimating the value and incidence of noncash incomes - private as well as public - was one of three related objectives of the project as a whole. See http://www.iser.essex.ac.uk/research/euromod/aim-ap-project for more information. We are grateful to Tim Callan, Francesco Figari, Joachim Frick, Tim Smeeding, Gerlinde Verbist and Francesca Zantomio, on whose work we draw heavily. We also thank the other project participants for their contributions of national-level analysis, as well as for valuable discussions and insights: Conchita d'Ambrosio, Kieran Coleman, Chiara Gigliarano, Tim Goedemé, Markus Grabka, Olaf Groh-Samberg, Claire Keane, Christos Koutsambelas, Stijn Lefebure, Mattia Makovec, Killian Mullen and Klaas De Vos. We are also indebted to all past and current members of the EUROMOD consortium for the construction and development of EUROMOD. However, any errors and the views expressed in this paper are the authors' responsibility.
} 
IZA Discussion Paper No. 4581

November 2009

\section{NON-TECHNICAL SUMMARY}

The usual practice when performing inter-temporal or cross-country comparisons of inequality and poverty is to rely on distributions of disposable income. This practice may be misleading since an individual's command over resources is determined not only by her spending power over commodities she can buy in the market but also by resources available to her through the in kind provisions of the welfare state as well as private non cash incomes. The contribution of cash and non-cash income components to total (augmented) income is likely to vary considerably both across time and across countries, thus introducing biases in the corresponding comparisons.

The present paper provides estimates of the size and incidence of three publicly provided services (housing, education and health care) in five European countries (Belgium, Germany, Greece, Italy and the UK). Cross-country differences are considerable. In the five countries examined in the paper, the value of their services is equal to $17.5 \%-26.7 \%$ of total household disposable income. Yet, in all countries, the corresponding in kind transfers appear to reduced measured inequality and (relative) poverty very substantially. The effect is more pronounced in households with children or elderly persons.

Nevertheless, doubts are raised regarding the appropriateness of static incidence analysis that is standard practice in the corresponding literature - without adjusting the equivalence scales for the extra needs of households for education and health care services. Once equivalence scales are adapted to take proper account of differences in needs for health care and education across population members, the redistributive effect of the in kind public transfers appears to decline, but, in most countries, it is not eliminated. 


\section{Introduction}

A household's command over resources is determined not only by its spending power over commodities it can buy but also by resources available to the members of the household through the in kind provisions of the welfare state as well as private non cash incomes. The omission of non cash incomes from the concept of resources used in distributional studies may call into question the validity of comparisons, both time-series within a particular country and cross-sectional comparisons across countries. For example, comparing the income distributions of two countries, one where health services are primarily covered by private out of pocket payments and another where such services are provided free of charge by the state to the citizens is likely to lead to invalid conclusions about the relative degree of inequality and, perhaps, policy implications. Further, this omission can have important implications for the efficient targeting of resources aiming to reduce inequality or mitigate poverty.

Studies using national or cross-national information for developed countries employing a variety of techniques and examining the distributional effects of in kind public transfers, mainly in the fields of public education and public health care, suggest that in kind transfers are more equally distributed than disposable income and, thus, reduce aggregate inequality. ${ }^{2}$ In quantitative terms, cross-country differences in the effects of in kind transfers seem to be substantial, but it is not always clear whether such differences are genuine or can be attributed to methodological choices made by the researchers.

The aim of this paper is to extend previous analyses of the distributional effects of welfare state programs in rich countries and focus on three of the most important public transfers in kind, namely, public education services, public heath care services and public housing, and analyse their short-term distributional effects in a strictly comparable framework in five EU countries (Belgium, Germany, Greece, Italy and the UK). ${ }^{3}$ Unlike other publicly provided

\footnotetext{
2 See, for example, O'Higgins and Ruggles (1981), James and Benjamin (1987), Lampman (1988), Smeeding et al. (1993), Evandrou et al. (1993), Whiteford and Kennedy (1995), Steckmest (1996), McLennan (1996), Huguenenq (1998), Tsakloglou and Antoninis (1999), Antoninis and Tsakloglou (2001), Sefton (2002), Caussat et al. (2005), Jones et al. (2008), Harding et al. (2006), Aaberge and Langørgen, (2006), Garfinkel et al. (2006), Marical et al. (2006) and Wolff and Zacharias (2006).

${ }^{3}$ These countries vary substantially in their standard of living as approximated by GDP per capita and represent three of the four welfare state regimes encountered in developed countries: "Liberal" (UK), "Continental" (Germany, Belgium) and "Southern" (Italy, Greece) (Esping-Andersen, 1990; Ferrera, 1996). National expertise was an essential input into the analysis reported here. The AIM-AP project did not include expertise on any country belonging to the "Social democratic" welfare state regime and, hence, no such example is included in our analysis.
} 
services, such as those in the fields of national defence and public order, the benefits of health care and education are relatively easy to quantify and allocate to particular members of the population. In the countries considered in the paper public education and public health care services are (almost) universal benefits, while in-kind public housing (where it exists) is largely targeted on those with greater housing needs, who tend to be those on lower incomes.

The methods of calculating the value of each of the three sources of in kind benefits are described in the next section and ways of identifying beneficiaries are discussed. In order to carry out distributional analysis, their incidence is measured by allocating them to appropriate individuals or households within income surveys for each country, which are also described. This is followed by a presentation of the main results of the distributional analysis, showing the effects of the three non cash elements of income in terms of their relative importance in aggregate and across the cash income distribution. Their effects are compared with those of the cash benefits systems and their overall impact on measures of inequality and poverty are described. The following section discusses the welfare interpretation of the empirical findings and outlines an alternative approach using different sets of equivalent scales, providing some empirical illustrations. A final section concludes.

\section{Methods and Data}

The main guiding principle that is adopted in calculating the monetary value of each of the three in kind transfers, and in allocating them to households, is to do so in a manner that is comparable across the five countries considered. As far as possible, the micro-data used to provide information on characteristics and cash income are taken from household survey

sources that are broadly comparable in terms of methods used to collect them, period in time and content (Table 1). Our results cover the effects on the whole population living in households rather than other institutions in each country. The household samples are large ranging from 5,275 in Belgium to 28,860 in the UK, as shown in Table 1 . These data were chosen because they also provide the input data for EUROMOD, the EU tax-benefit microsimulation model which is described in more detail at the end of this section. As well as allowing us to establish the distributional effects of the three non cash benefits, using our estimates within EUROMOD also enables the size and effects of the non cash benefits to be compared with those of cash benefits and direct taxes, as included in standard measures of disposable income. The income distributions augmented with non cash benefits can be used to evaluate the distributional effects of cash policy changes and, in specific circumstances the 
Table 1. Income data sets used in the analysis

\begin{tabular}{|c|c|c|c|c|c|c|}
\hline \multirow[b]{2}{*}{ Country } & \multirow[b]{2}{*}{ Dataset } & \multirow{2}{*}{$\begin{array}{l}\text { Date of } \\
\text { collection }\end{array}$} & \multirow{2}{*}{$\begin{array}{l}\text { Reference } \\
\text { period for } \\
\text { incomes }\end{array}$} & \multicolumn{3}{|c|}{ Sample sizes } \\
\hline & & & & $\begin{array}{r}\text { House- } \\
\text { holds }\end{array}$ & Children & Elderly \\
\hline Belgium & EU-SILC & 2004 & 2003 & 5,275 & 2,945 & 1,881 \\
\hline Germany & $\begin{array}{l}\text { German Socio- } \\
\text { Economic Panel }\end{array}$ & 2002 & 2001 & 11,194 & 5,658 & 3,753 \\
\hline Greece & $\begin{array}{l}\text { Household Budget } \\
\text { Survey }\end{array}$ & $2004 / 5$ & 2004 & 6,555 & 3,011 & 3,830 \\
\hline Italy & $\begin{array}{l}\text { Italian version of } \\
\text { EU-SILC }\end{array}$ & 2004 & 2003 & 24,204 & 10,335 & 11,041 \\
\hline UK & $\begin{array}{l}\text { Family Resources } \\
\text { Survey }\end{array}$ & $2003 / 4$ & $2003 / 4$ & 28,860 & 16,585 & 11,047 \\
\hline
\end{tabular}

Acknowledgment: EUROMOD data sources are the EU Statistics on Incomes and Living Conditions (EU-SILC) made available by Eurostat (under contract EU-SILC/2007/03); the public use version of the German Socio Economic Panel Study (GSOEP) made available by the German Institute for Economic Research (DIW), Berlin; the Greek Household Budget Survey (HBS) made available by the National Statistical Service of Greece; the Italian version of the EU-SILC made available by ISTAT; and the Family Resources Survey (FRS), made available by the UK Department for Work and Pensions (DWP) through the Data Archive. Material from the FRS is Crown Copyright and is used by permission. None of the data providers bears any responsibility for the analysis or interpretation of the data reported here.

Notes: Children are defined as persons aged 17 or below; elderly are defined as persons aged 65 or above.

non cash elements can be manipulated to expand the scope of policy changes that can be examined by EUROMOD.

The estimates of inequality indices derived in the later sections of the paper rely on static incidence analysis under the assumption that public transfers in kind do not create externalities. No dynamic effects are considered in the present analysis. In other words, it is assumed that the beneficiaries of the public transfers are exclusively the recipients of the transfers (and the members of their households). Any benefits such services might create (such as a healthy and educated workforce) or losses to the non-recipients are excluded from the analysis. Of course, the presence of non cash benefits means that taxes are higher than they otherwise would be. Non cash benefits are typically financed from many sources, including the direct taxes and social insurance contributions paid by both recipients and non-recipients.

Moreover, in the cases of public education and public health care it is assumed that the value of the transfer to the beneficiary is equal to the average cost of producing the 
corresponding services. ${ }^{4}$ Similar assumptions are standard practice in the analysis of the distributional impact of publicly provided services (Jones et al., 2008; Marical et al., 2006; Smeeding et al., 1993). 5

The following three sub-sections describe how the estimates of non cash income were derived for each of the three components.

\section{Education}

Information on spending per student in primary, secondary and tertiary education is derived from OECD (2006). Each student in a public education institution (or a heavily subsidized private education institution) identified in the income survey (see Table 1) is assigned a public education transfer equal to the average cost of producing these services in the corresponding level of education. Then, this benefit is assumed to be shared by all household members. In other words, it is implicitly assumed that in the absence of public transfers the students and their families would have to undertake the expenditures themselves.

Because of limitations on the information available on education in some of the income surveys we focus on three levels of education (primary, secondary and tertiary), thus leaving aside other levels such as pre-primary education and suppressing distinctions, such as those between different types of secondary and tertiary education which may be important in some countries. Estimates of public spending per student in primary, secondary and tertiary public education institutions were derived using the information of OECD (2006) and they are shown in Table 2 (estimates in current euros). ${ }^{6}$

\footnotetext{
${ }^{4}$ In order to preserve cross country comparability, the estimates of public education transfers by level of education and public health care transfers by age group do not vary by region within countries. However, in countries where public education and/or public health care are organized at the regional level and the relevant information is available, estimates were also derived exploiting the corresponding regional variation. The results can be found in the national reports that are available in AIM-AP's website, but they are not substantially different from the results reported below.

${ }^{5}$ Naturally, if it is assumed that the public sector is less efficient in producing these services than the private sector, our results as well as the results of almost all empirical studies in the field may overestimate their redistributive effects. However, no strong evidence of such inefficiencies can be found in the literature (see, for example, Willner and Parker (2007) who conclude that "Thus while public sector inefficiency is sometimes seen as a stylised fact, it appears from the empirical evidence that a change of ownership from public to private is not necessarily a cure for an under-performing organisation. In a different framework, see Afonso and St. Aubyn (2005) and Afonso et al.(2005) who examine the efficiency of the public sector in a comparative cross-sectional setting.

${ }^{6}$ More specifically, figures from Table X2.5 (p. 434) (Annual expenditure on educational institutions per student for all services (2003) in equivalent euros converted using PPP, by level of education based on full-time equivalents) were multiplied by the estimates of the share of public expenditures
} 
Table 2. Public spending per student in three educational levels (in current euros)

\begin{tabular}{lccc}
\hline & \multicolumn{3}{c}{ Level of education } \\
\cline { 2 - 4 } Country/year & Primary & Secondary & $\begin{array}{c}\text { Tertiary } \\
\text { (without R\&D) }\end{array}$ \\
\hline Belgium 2003 & 4662 & 5814 & 5809 \\
Germany 2001 & 3131 & 4857 & 5410 \\
Greece 2004 & 2541 & 2984 & 2772 \\
Italy 2003 & 5310 & 5723 & 3264 \\
UK 2003 & 3989 & 4972 & 5207 \\
\hline Source: OECD (2006) & & &
\end{tabular}

Source: OECD (2006).

In all countries public spending per secondary education student is higher than the corresponding figure for primary education. However, in some countries such as Germany and Belgium the differences are quite large, while in others, such as Italy and Greece, the differences appear to be relatively small. Comparisons of spending per student in tertiary education depend on the treatment of public R\&D expenditures. Because their main beneficiaries are not the students, estimates of public transfers to tertiary education students are calculated net of R\&D public expenditures.

Tertiary education students living away from their parental homes pose the broader question of whether household income is a good approximation of their standard of living. Analysis which simply looks at all students, risks attributing an unwarranted benefit to students who appear to have low incomes simply because they moved temporarily away from high income parental homes for the period of their studies; while the literature on the returns to education indicates that their likely positions in the earnings distribution will be towards the top. Moreover, the living arrangements of tertiary education students differ substantially across countries, while their treatment in the national surveys is not always the same. For example, most of tertiary education students in Greece live with their parents whereas this is the case for relatively few students in the UK. In Belgium and Italy students living in student accommodation are treated as members of their parental households in the

in total educational expenditures (separately for tertiary and non-tertiary education) reported in Table B2.1b (p. 206) (Expenditure on educational institutions as a percentage of GDP by level of education (1995, 2000, 2003) from public and private sources by source of funds and year) and euro PPP conversion rates as reported in Table X2.2 (p. 431) (Basic reference statistics (reference period: calendar year 2003, 2003 current prices). Then, in order to derive the corresponding estimates for years other than 2003, these estimates were inflated or deflated using country specific nominal GDP per capita conversion factors derived from the data of the on-line OECD database (using real GDP growth rates, GDP deflators and population growth rates). 
income surveys; in the UK they are not included at all. Therefore, the corresponding results should be treated with caution. It should be noted that in the UK there is a substantially more important role for private sources in funding tertiary education than in other countries, in the form of student fees. ${ }^{7}$

Figure 1. Distribution of public education beneficiaries by quintile of household disposable (cash) income and by level of education

Primary Education

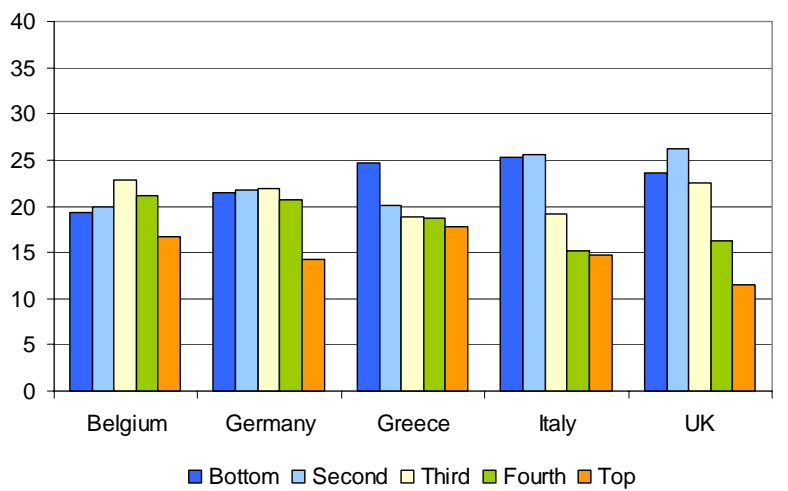

Tertiary education

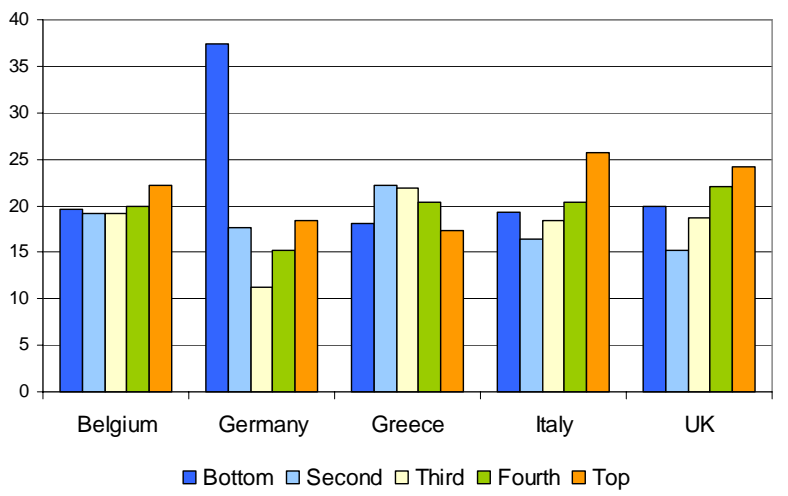

Secondary education

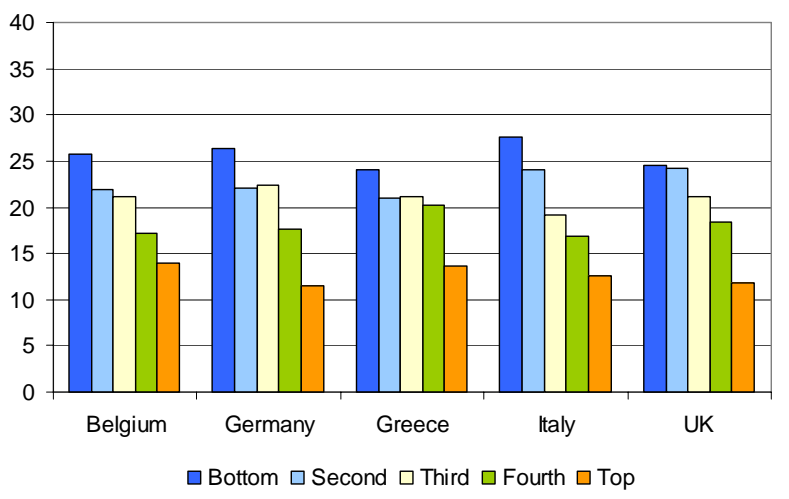

All levels

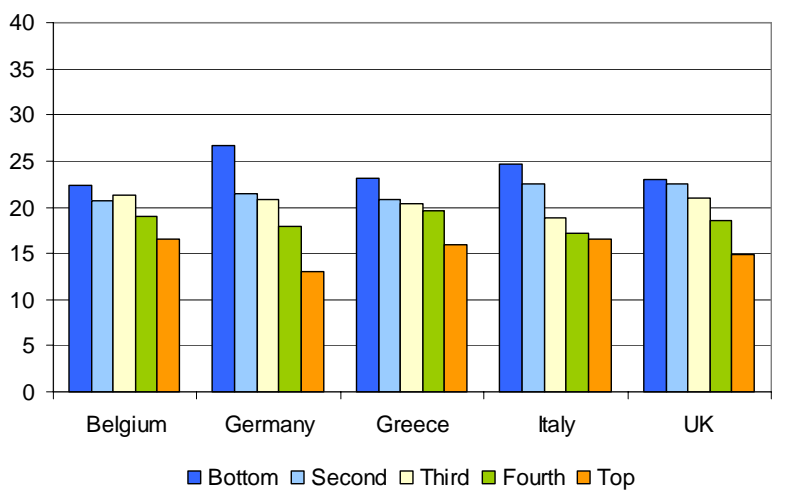

Source: EUROMOD

Notes: Quintile points are defined on the basis of equivalised household disposable income, allocated to individuals, using the modified OECD equivalence scale. Beneficiaries are individuals participating in the relevant level of education.

Figure 1 shows the position of the individual beneficiaries of public education subsidies in the distribution of equivalised household disposable income for primary, secondary and

7 For a detailed discussion see Callan et al. (2007). As shown there, if tertiary education students living away from the parental home are excluded from the analysis, the incidence of public education transfers appears to be marginally less progressive than reported below, but in qualitative terms the results are hardly affected. 
tertiary education. ${ }^{8}$ Bars higher (lower) than 20 percent indicate that the quintile groups under consideration contain proportionally more (fewer) beneficiaries than their population shares. The top left graph depicts the situation regarding primary education. In Belgium and Germany, the beneficiaries of public primary education transfers appear to be fairly evenly distributed across the first four quintiles, while in the rest of the countries they seem to be disproportionately concentrated lower down the cash income distribution. In all countries, especially in Germany and the UK, they are substantially underrepresented in the top quintile. A similar picture emerges in the top right graph which shows that in all countries there is a negative relationship between the share of beneficiaries of public secondary education and the quintile of the income distribution. In the cases of Greece and the UK this can be partly attributed to the fact that the (relatively few) private education students are concentrated to the upper part of the cash income distribution (especially the top quintile). Such students cannot be identified in the income surveys of the remaining countries. Moreover, in all countries high earning individuals or couples without children are overrepresented in the top quintiles.

The bottom left graph shows the location of public tertiary education beneficiaries in the income distribution. No clear cross-country pattern emerges, although with the exception of Greece there is a U-shaped pattern with more beneficiaries at the top and the bottom than in the middle. The higher shares of beneficiaries at the bottom, especially notable in Germany, can be attributed to a large number of single person (student only) households, naturally with low levels of current income. As explained above, cross-country differences in the living circumstances of tertiary-level students and the exclusion of students living in institutional accommodation may explain the observed effects. The bottom right chart combines all levels of education and shows how, in all countries, beneficiaries are underrepresented in the top and, in most cases, the fourth quintile, while they are overrepresented in the three lowest quintiles.

\section{Health}

Similar to education, the most often-used method in the literature of the distributive evaluation of health care services accounts for the distributional impact of health care services by increasing household income by the sum of the corresponding public

\footnotetext{
${ }^{8}$ Following the practice of EUROSTAT, in the main body of the paper income is equivalised using the modified OECD equivalence scale - with weights of 1.0, 0.5 and 0.3 assigned to the household head, each other household member aged above 13 and each member aged below 14, respectively.
} 
expenditures. Three approaches can be distinguished in this context: 1) the actual consumption approach; 2) the insurance value approach; and 3) using equivalence scales that incorporate health care needs.

The actual consumption approach uses detailed data on the effective use of health care services by individuals (see, for example, Evandrou et al. (1993) and Sefton (2002) for the UK). A fundamental critique of this approach states that it ignores the greater needs that are associated with being ill (Aaberge and Langørgen, 2006). It implies that, ceteris paribus, sick people are better off than healthy persons just because they receive more health care services. In fact, it has been clearly demonstrated that poorer individuals tend to have lower health levels, and consequently greater needs for health care (see, for example, HernandezQuevedo et al. (2006) and Berloffa et al. (2006)). Furthermore, since usually health care spending is concentrated heavily in the last year of an individual's life ("death related costs") adoption of this approach results in extensive re-rankings of elderly people in the income distribution and hence, misleading results.

Using the insurance value approach, the 'insurance value' of coverage for each person is imputed based on specific characteristics (such as age, sex, socio-economic status, etc). The insurance value is the amount that an insured person would have to pay in each category so that the third party provider (government, employer, other insurer) would have just enough revenue to cover all claims for such people (Smeeding, 1982). It is based on the notion that what the public health care services provide is equivalent to funding an insurance policy where the value of the premium is the same for everybody sharing the same characteristics, such as age (Marical et al., 2006). Nevertheless, a problem remains since the relative needs of individuals for health care are not the same as for commodities bought in the market. Different equivalence scales should be used in the two distributions (disposable income and disposable income plus the value of public health care services).

Therefore, a third approach, which has considerable informational requirements, is to use the insurance-based approach and introduce an equivalence scale that corrects for differences in health care needs between individuals. The problem with this approach, however, lies in the choice of the equivalence scale. No attempt to construct sets of equivalence scales covering differences in needs for the entire population exists, although a number of empirical studies focusing on particular population groups or specific situations can be found in the literature (Jones and O'Donnell, 1995; Klavus, 1999; Zaidi and Burchardt, 2005; Berloffa et al., 2006). Nevertheless, the welfare foundations of these studies are not always 
straightforward (Radner, 1997). The problem of the appropriate equivalence scales and the welfare interpretation of the corresponding incidence analysis are discussed further below.

The present paper uses the risk-related insurance value approach. Following this approach, each individual is assumed to receive a public benefit determined by the average spending on his/her age group irrespective of whether use of public health services was actually made. As such, this method is similar to how the education non cash benefits were determined, except that the health benefits are assigned to everybody. Then, this benefit is added to the resources of the household to which this individual belongs. We calculate per capita expenditures for each age group using the OECD Social Expenditure database (SOCX), which provides data that are comparable across countries. ${ }^{9}$

Figure 2. Public health care expenditures (in nominal Euro) per capita by age group

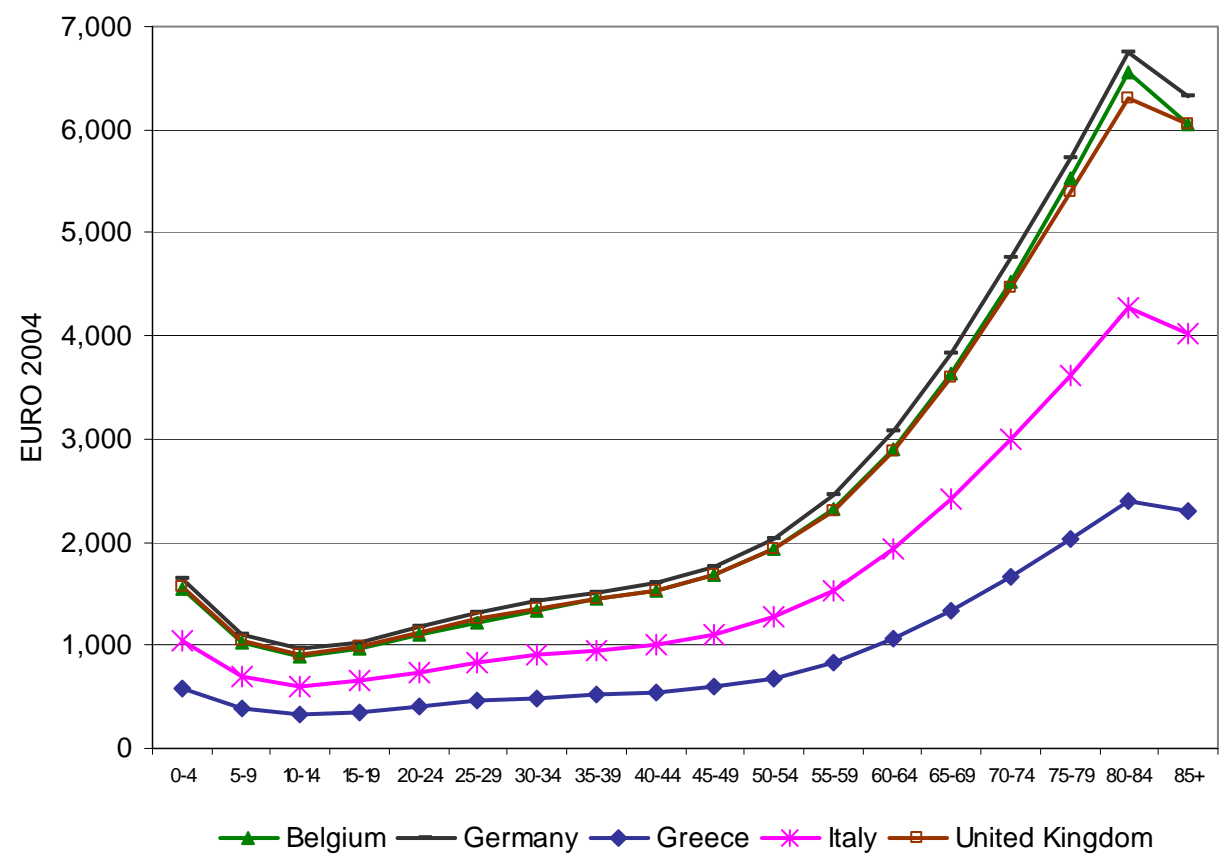

Source: Calculations based on OECD Social Expenditure database.

9 The health care expenditures are taken from the OECD Health Data and include all public expenditure on health care, including among other things, expenditure on in-patient care, ambulatory medical services, pharmaceutical goods and prevention. They do not include non-reimbursed individual health expenditures or cash benefits related to sickness. One drawback of the SOCX database arises from the fact that it does not distinguish differences in the use of health care by men and women although there is evidence that spending patterns differ across sexes (Costello and Bains, 2001; Carone et al., 2005). Another issue is that R\&D spending is included. It may be argued that this component is not relevant for current welfare but the SOCX database does not allow its deduction from the concept of public health care transfers (see Smeeding et al. (2008) for further discussion). 
The age pattern is the same as that used in Marical et al. (2006) and is shown in Figure 2. As expected, spending per capita is considerably higher for older people. The distributional impact of health care spending is, therefore, likely to be determined to a considerable extent by the location of the elderly in the income distribution. As shown in Table 3 which reports the relative mean per capita public health care expenditure by quintile of equivalised household disposable income, health care spending is higher (lower) than average for lower (higher) income households. The cross-country pattern by income is similar in all cases but less marked in Italy and Germany than in the other countries. ${ }^{10}$

Table 3. Relative mean per capita public health care transfer per quintile of household cash disposable income

\begin{tabular}{cccccc}
\hline Quintile & Belgium & Germany & Greece & Italy & UK \\
\hline 1 (bottom) & 1.17 & 1.05 & 1.11 & 0.98 & 1.10 \\
2 & 1.17 & 1.06 & 1.11 & 1.03 & 1.10 \\
3 & 0.95 & 0.99 & 1.00 & 1.04 & 1.02 \\
4 & 0.87 & 0.95 & 0.90 & 0.99 & 0.92 \\
5 (top) & 0.84 & 0.96 & 0.88 & 0.96 & 0.85 \\
\hline All & 1.00 & 1.00 & 1.00 & 1.00 & 1.00 \\
\hline
\end{tabular}

Source: EUROMOD

Notes: Quintile points are defined on the basis of equivalised household disposable income, allocated to individuals, using the modified OECD equivalence scale.

\section{Housing subsidies}

Public support for housing costs can take many forms. Some of these are captured in the measurement of cash household disposable income. Housing benefits paid in cash and tax relief on mortgage interest are examples of common forms that are usually accounted for in cash income measures. However, cross-country (or inter-temporal) comparisons of the

10 The financing of health care services varies substantially across the countries considered in the paper. In Italy and the UK they are funded primarily out of general taxes, in Germany and Belgium the main source is social insurance contribution, while in Greece general taxes and social security taxes are equally important but private out of pocket payments are very significant. In a life-cycle context it is important to disentangle the insurance and the transfer element in public health care transfers in kind and, in fact, some efforts have been made in this direction using different approaches (Rochet, 1991; Wagstaff et al, 1999; Borsch-Supan and Reil-Heidl , 2001; Ter Rele, 2007). However, in the context of the present paper the focus of the analysis is on short-run effects, taxes and social insurance contributions are given and the analysis focuses on the, ceteris paribus, partial effects of these transfers. 
Table 4. Social tenants (percent of all households) by quintile of household cash disposable income

\begin{tabular}{cccccc}
\hline Quintile & Belgium & Germany & Greece & Italy & UK \\
\hline 1 (bottom) & 10.3 & 10.8 & 0.2 & 1.5 & 30.6 \\
2 & 7.3 & 7.9 & 0.0 & 0.8 & 35.5 \\
3 & 3.1 & 5.9 & 0.1 & 0.4 & 19.3 \\
4 & 2.4 & 5.2 & 0.1 & 0.4 & 9.6 \\
5 (top) & 1.8 & 2.2 & 0.1 & 0.1 & 1.9 \\
\hline All & 5.2 & 6.5 & 0.1 & 0.7 & 19.5
\end{tabular}

Source: EUROMOD

Notes: Quintile points are defined on the basis of equivalised household disposable income, allocated to individuals, using the modified OECD equivalence scale.

extent and incidence of public housing support are compromised if these forms of assistance are captured and direct subsidies are not. To redress this situation we estimate the extent to which tenants in the social rented sector are paying rent below the amount they would pay if they were renting the same accommodation in the private market. Actual rent paid (calculated gross of any cash housing benefit) by social sector tenants is recorded in the income survey datasets underlying our analysis. Market rents must be estimated. The method that is adopted is "borrowed" from the methods developed to estimate the value of imputed rents for owner occupiers (Frick and Grabka, 2003). The approach, known as the "rental equivalence" method, considers the opportunity cost of housing in non-subsidized rental markets. It is based on a hedonic regression approach, following a two-step procedure. First, a regression model is estimated for the population of tenants (or rented accommodations) in the private, non-subsidized market with rent as the dependent variable. Explanatory variables may include characteristics of the dwelling and the occupants. ${ }^{11}$ The second stage applies the resulting coefficients to otherwise similar social tenants (see Frick et al. (2008) for further discussion). Table 4 shows that the proportion of households in the social rented sector varies considerably from almost none in Greece and very few in Italy to

11 This straightforward approach can be further improved by correcting for potential selectivity into the owner status (e.g., by applying a Heckman selection correction) as well as by considering measurement error in the imputation process, i.e., by adding an error term to the imputed rental value, thus maintaining the variance in the final construct. The practical solution found for the five countries considered here varied both in terms of the precise method (the Heckman correction was not successfully employed for the UK and Italy) and the explanatory variables that were chosen. Each country used broadly the same approach, while using the available variables that were most applicable to national housing markets. Due to space limitations no detailed regression results are reported here, but they are available in the AIM-AP project web-page cited in the acknowledgments, or on request. 
almost 20 percent in the UK. In all countries they are concentrated, but not located exclusively, in the lower income quintiles.

\section{EUROMOD}

Our analysis makes use of EUROMOD, a unique tax-benefit microsimulation model that covers EU member states in a comparable way. It uses micro-data derived from representative household income surveys, as shown in Table 1 for this study. It simulates direct tax liabilities, social insurance contributions and benefit entitlements for the households and their members. It is a static model, appropriate for the analysis of short-term effects and designed to inform many types of analysis (Sutherland, 2007; Lietz and Mantovani, 2007). In the context of the present paper, using EUROMOD allows us to decompose the components of disposable income in a comparable manner, and to compare the size and distributional effects of these components with non cash benefits. ${ }^{12}$

The main "outcome" measure from EUROMOD is disposable income, that is gross market income plus private transfers less income taxes, including local taxes, and social insurance contributions (paid by employees and the self-employed), plus cash benefits. Disposable income measured at the household level and equivalised to account for differences in household size and composition is the income concept that makes up the usual measuring stick employed in studies of poverty and income distribution in Europe and most other developed counties. Since this concept of income includes only a selection of taxes and items of public spending, it provides only a partial picture of the effect of the public sector on household welfare. On the one hand the incidence of indirect and corporate taxes and employer social contributions is omitted. On the other hand, public expenditure for health care, education and housing, together with spending in areas such as public order and national defense are also not incorporated.

In the analysis reported below we improve the comprehensiveness of the income measure by including public transfers in kind in the fields of education, health care and housing. It should be noted that our analysis is short-run and "partial". In other words, our data do not allow it and we do not aim to examine the long term consequences of public transfers in kind or the aggregate life-cycle effects of cash and non-cash transfers on the one hand and taxes and social insurance contributions on the other. At any given point in time, taxes are

12 The inclusion of non cash benefits does not affect the tax-benefit calculations. For example, where actual rent paid affects housing benefit entitlements, these actual expenditures (not the imputed value of rent) are used in the simulation of housing benefit component of cash income, throughout the analysis. 
given and are not earmarked. Our attempt is to provide a more comprehensive measure of resources than that used in most distributional studies and compare the baseline (disposable income) with the augmented (disposable income plus in kind public benefits) distribution. By adding non cash incomes the analysis is more comprehensive and cross-country comparability is improved.

\section{Incidence of public non cash transfers}

In this section we consider the effects of the combination of the three public transfers across the income distribution. First the scale of the transfer via non cash benefits is contrasted with that of cash benefits, as illustrated in Figure 3. The left-hand chart shows the composition, across all households, of "augmented" income (cash disposable income plus non cash income), in terms of the average size of each income component as a percentage of augmented household income as a whole. As such it shows how much market income is necessary on average to achieve a given level of augmented income; how much is added as cash and non cash benefits and deducted as direct taxes and social insurance contributions. Cash benefits are sub-divided in Figure 3 into (i) public pensions and (ii) other cash benefits. In all five countries cash benefits, taking the two types together, play a larger role in augmented income than non cash benefits, but the extent to which this is so varies. At one extreme, in the UK the proportions are similar with cash benefits making up 19 percent and non cash benefits 17 percent. At the other extreme (Greece and Italy) the contribution of non cash transfers considered here is much smaller than that of cash transfers, largely because of the importance of public pensions on the cash side. In Belgium and Germany both cash and non cash benefits are relatively large components of income but cash benefits including pensions make up the larger share.

The middle chart shown in Figure 3 illustrates the composition of augmented income in the bottom decile group, (using equivalised augmented income to rank households). Both cash and non cash benefits are more important at low levels of income. Cash benefits are more closely (but inversely) related to income than are non cash benefits - so the share of non cash in all benefits is lower in the bottom decile group than overall. In the top decile group, shown on the right of Figure 3, both cash and non cash benefits are clearly less important. In the case of the UK non cash benefits are larger than cash benefits. In all the other countries, mainly because of the role of public pensions, cash maintains the same relative role in benefits as a whole in the top income group as it does for all households. Figure 3 also shows the relative size of direct taxes and contributions paid by households. While the top decile 
Figure 3. Composition of augmented household incomes, including non cash benefits (housing subsidies, education and health)

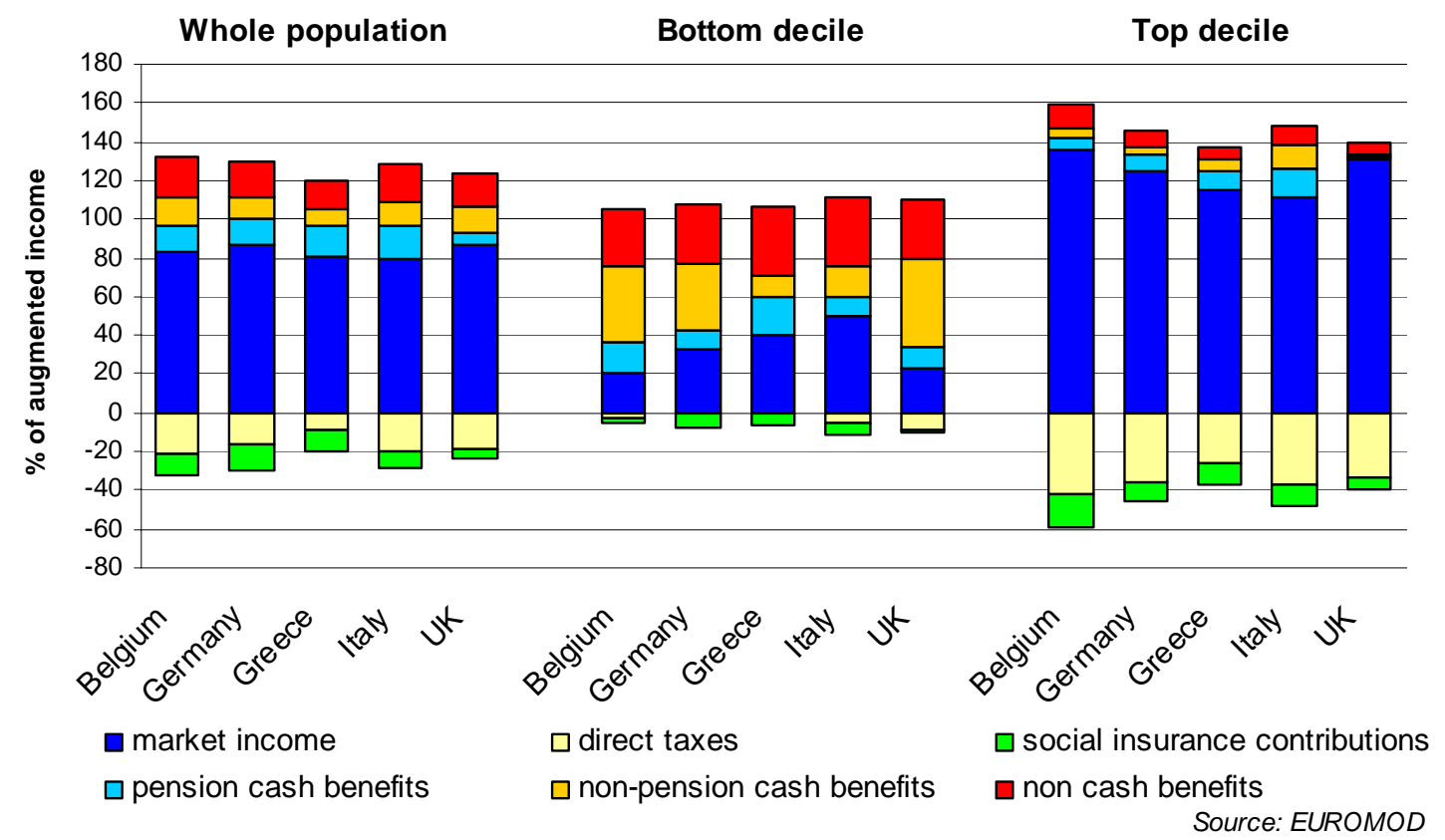

Notes: Decile groups are defined for individuals using household disposable income augmented with non cash benefits and equivalised using the modified OECD scale. Income composition is calculated per household on a non-equivalised basis.

group pays more in these taxes than it receives back in cash and non cash benefits, the reverse is strongly the case in the bottom decile group, with the contrast being particularly clear for Belgium.

Next, we consider the size of each of the three non cash components, measured relative to cash disposable income. The top panel of Table 5 shows that public rent subsidies make up a tiny proportion of the combined non cash transfers that we consider, even in the countries where they affect a significant number of households (Table 4). Their largest effect is in the UK where they are equal to 1 percent of cash disposable income. Public spending on education and health each has a much bigger effect in all countries. Education transfers in kind are equal to nearly 10 percent of disposable income in Belgium, which has the highest spending relative to disposable income, while the lowest percentage is 6 percent, in Germany. Health makes a larger aggregate contribution than education in all five countries. It contributes most in Belgium and Germany (16 to 17 percent), followed by Italy (15 percent), UK (13 percent) and Greece with 12 percent. Added together the three non cash transfers that we consider represent the largest proportional addition to cash income in 
Table 5. Non cash benefits as a percentage of cash household disposable income by country and income quintile

\begin{tabular}{|c|c|c|c|c|}
\hline & $\begin{array}{c}\text { Rent } \\
\text { subsidy }\end{array}$ & Education & Health & Combined \\
\hline & \multicolumn{4}{|c|}{ I. All households } \\
\hline Belgium & 0.3 & 9.9 & 16.6 & 26.7 \\
\hline Germany & 0.7 & 6.3 & 16.7 & 23.7 \\
\hline Greece & 0.0 & 6.0 & 11.5 & 17.5 \\
\hline Italy & 0.0 & 8.4 & 14.9 & 23.4 \\
\hline \multirow[t]{2}{*}{ UK } & 1.0 & 6.8 & 13.2 & 21.0 \\
\hline & \multicolumn{4}{|c|}{ II. Bottom quintile } \\
\hline Belgium & 1.1 & 20.9 & 36.4 & 58.4 \\
\hline Germany & 3.0 & 18.1 & 36.6 & 57.7 \\
\hline Greece & 0.0 & 18.9 & 34.9 & 53.8 \\
\hline Italy & 0.1 & 28.1 & 38.4 & 66.6 \\
\hline \multirow[t]{2}{*}{ UK } & 4.7 & 19.6 & 35.3 & 59.7 \\
\hline & \multicolumn{4}{|c|}{ III. Top quintile } \\
\hline Belgium & 0.1 & 4.9 & 8.3 & 13.3 \\
\hline Germany & 0.2 & 2.2 & 8.6 & 10.9 \\
\hline Greece & 0.0 & 2.4 & 5.2 & 7.6 \\
\hline Italy & 0.0 & 3.4 & 7.5 & 10.9 \\
\hline UK & 0.0 & 2.3 & 5.5 & 7.9 \\
\hline
\end{tabular}

Notes: Quintile points are defined on the basis of equivalised household disposable income, allocated to individuals, using the modified OECD equivalence scale.

Belgium (27 percent) followed by Germany and Italy (23 to 24 percent), and the UK (21 percent), with the addition in Greece being the lowest (18 percent).

The middle panel of Table 5 shows that in all countries each of the three types of non cash benefits (where they exist) contributes proportionally more to the incomes of the bottom quintile group than to the incomes of the entire population. This, and the smaller effects for the top quintile group (reported in the bottom panel of Table 5) indicates the extent to which non cash benefits are more equally distributed than cash disposable income. Compared to the average proportion, the effect on the resources of the bottom quintile is particularly large in Italy and the UK. However, this is also due to the fact that the share of the bottom quintile in the cash income distribution in these countries is relatively low (and, certainly, lower than in Belgium and Germany). 
Table 6. Quintile shares (percent) for cash and augmented equivalised household income

\begin{tabular}{|c|c|c|c|c|c|c|}
\hline & \multirow[b]{2}{*}{ Quintiles } & \multicolumn{5}{|c|}{ Household income } \\
\hline & & Cash only & $\begin{array}{l}\text { Cash + } \\
\text { in kind } \\
\text { rent } \\
\text { subsidy }\end{array}$ & $\begin{array}{c}\text { Cash + } \\
\text { education }\end{array}$ & $\begin{array}{l}\text { Cash + } \\
\text { health }\end{array}$ & $\begin{array}{c}\text { Cash }+ \text { all } \\
3 \text { public } \\
\text { non cash } \\
\text { transfers }\end{array}$ \\
\hline \multirow{5}{*}{ Belgium } & 1 & 10.3 & 10.3 & 11.5 & 11.9 & 12.9 \\
\hline & 2 & 15.0 & 15.1 & 15.7 & 16.1 & 16.6 \\
\hline & 3 & 18.8 & 18.7 & 19.1 & 18.9 & 19.1 \\
\hline & 4 & 23.1 & 23.0 & 22.7 & 22.4 & 22.1 \\
\hline & 5 & 32.9 & 32.8 & 31.1 & 30.7 & 29.3 \\
\hline \multirow{5}{*}{ Germany } & 1 & 9.3 & 9.5 & 10.4 & 10.8 & 11.9 \\
\hline & 2 & 13.8 & 13.9 & 14.4 & 14.9 & 15.3 \\
\hline & 3 & 17.6 & 17.6 & 17.9 & 18.0 & 18.2 \\
\hline & 4 & 23.0 & 22.9 & 22.6 & 22.4 & 22.2 \\
\hline & 5 & 36.3 & 36.1 & 34.7 & 33.9 & 32.5 \\
\hline \multirow{5}{*}{ Greece } & 1 & 7.3 & 7.3 & 8.3 & 8.7 & 9.6 \\
\hline & 2 & 12.9 & 12.9 & 13.4 & 13.8 & 14.2 \\
\hline & 3 & 17.3 & 17.3 & 17.5 & 17.6 & 17.8 \\
\hline & 4 & 23.1 & 23.1 & 22.9 & 22.6 & 22.5 \\
\hline & 5 & 39.4 & 39.4 & 37.9 & 37.2 & 36.0 \\
\hline \multirow{5}{*}{ Italy } & 1 & 7.7 & 7.7 & 9.3 & 9.2 & 10.5 \\
\hline & 2 & 13.4 & 13.4 & 14.3 & 14.3 & 15.0 \\
\hline & 3 & 17.8 & 17.8 & 17.9 & 18.2 & 18.2 \\
\hline & 4 & 23.3 & 23.3 & 22.7 & 22.9 & 22.4 \\
\hline & 5 & 37.8 & 37.8 & 35.8 & 35.5 & 33.8 \\
\hline \multirow{5}{*}{ UK } & 1 & 8.3 & 8.6 & 9.5 & 9.8 & 11.0 \\
\hline & 2 & 12.3 & 12.5 & 13.2 & 13.4 & 14.3 \\
\hline & 3 & 16.6 & 16.6 & 17.0 & 17.1 & 17.3 \\
\hline & 4 & 22.7 & 22.5 & 22.3 & 22.2 & 21.8 \\
\hline & 5 & 40.1 & 39.7 & 38.0 & 37.5 & 35.6 \\
\hline
\end{tabular}

Source: EUROMOD

Notes: Quintiles are fixed and based on equivalised cash household disposable income

The relative contributions of each source of non cash benefit in reducing inequality as we move from the distribution of disposable income to the distribution of augmented income are shown in Table 6 in terms of their effect on quintle shares. Non cash benefits as a whole 
have a rather similar and common absolute effect on quintile shares across the five countries considered, in each case increasing the share of the bottom two quintiles and reducing the share of the top quintile, while the effect on the third is slightly positive and on the fourth, slightly negative. The relative contributions of health and education are similar across countries although education seems to play a larger and more strongly redistributive role in Italy than in other countries, increasing the share of the bottom quintile group by 1.7 percentage points and reducing that of the top quintile group by 2.1 points. To a lesser extent, the same applies to health in Belgium, where the share of the bottom quintile group increases by 1.6 percentage points, compared with between 1.4 and 1.5 points in all other countries. As expected from earlier results, the contribution of housing subsidies to changing quintile shares is small in all countries with the largest effects being an increase in the share of the bottom quintile group in the UK of 0.3 percentage points (corresponding to a transfer equivalent to 5 percent of the cash income of the quintile).

Not surprisingly, the effect of adding non cash transfers to cash income is to reduce inequality. (We consider the welfare interpretation of such a measure in the next section.) As shown in Table 7, inequality using the augmented measure is lower in all countries than for cash income alone, for each of the three inequality indexes considered (the Gini coefficient, and the Atkinson index with inequality aversion parameters set to 0.5 and 1.5). The proportional reduction in inequality is largest in Belgium and smallest in Greece, and is generally in line with the relative sizes of the non cash transfers and cash income (shown in Table 5). In the case of the UK the inequality reduction is higher than the size of the transfers alone would indicate, implying that non cash transfers may be better targeted to the lower tail of the distribution. Table 7 also shows the effect on the three inequality indicators of each of the non cash components separately. Public health spending has the largest inequality reducing effect, followed by public education spending, while public rent subsidies in kind do not make any statistically significant difference. In line with the results for quintile shares, public healthcare has a somewhat larger inequality-reducing effect in Belgium than in other countries with the same applying to education in Italy. Nevertheless, it is also worth noting that the inequality ranking of the five countries hardly changes when we move from the distribution of monetary income to the distribution of augmented income. The only reranking observed is that between Belgium and Germany when the Atkinson (1.5) index is used. Furthermore Greece's position with the highest inequality, using the Gini coefficient, only becomes statistically significant once all three non cash benefits are included. 
Table 7. Inequality indicators for cash and augmented equivalised household income

\begin{tabular}{|c|c|c|c|c|c|c|c|}
\hline \multirow[t]{2}{*}{ Country } & \multirow{2}{*}{$\begin{array}{l}\text { Household income } \\
\text { concept }\end{array}$} & \multirow{2}{*}{\multicolumn{2}{|c|}{$\begin{array}{l}\text { Gini } \\
\text { confidence } \\
\text { interval }\end{array}$}} & \multicolumn{2}{|c|}{ Atkinson (0.5) } & \multicolumn{2}{|c|}{ Atkinson (1.5) } \\
\hline & & & & & $\begin{array}{c}\text { confidence } \\
\text { interval }\end{array}$ & & $\begin{array}{c}\text { confidence } \\
\text { interval }\end{array}$ \\
\hline \multirow[t]{5}{*}{ Belgium } & Cash only & 0.226 & $0.221-0.232$ & 0.045 & $0.043-0.048$ & 0.217 & $0.175-0.258$ \\
\hline & Cash + in kind rent subsidy & 0.225 & $0.220-0.230$ & 0.045 & $0.042-0.047$ & 0.208 & $0.165-0.250$ \\
\hline & Cash + education & 0.211 & $0.206-0.216$ & 0.040 & $0.037-0.042$ & 0.200 & $0.154-0.246$ \\
\hline & Cash + health & 0.192 & $0.187-0.197$ & 0.032 & $0.030-0.034$ & 0.102 & $0.096-0.108$ \\
\hline & Cash +3 non cash transfers & 0.175 & $0.170-0.179$ & 0.027 & $0.025-0.028$ & 0.086 & $0.080-0.091$ \\
\hline \multirow[t]{5}{*}{ Germany } & Cash only & 0.270 & $0.265-0.275$ & 0.059 & $0.057-0.061$ & 0.168 & $0.162-0.174$ \\
\hline & Cash + in kind rent subsidy & 0.267 & $0.262-0.272$ & 0.057 & $0.055-0.060$ & 0.164 & $0.158-0.170$ \\
\hline & Cash + education & 0.250 & $0.245-0.255$ & 0.051 & $0.049-0.053$ & 0.148 & $0.142-0.153$ \\
\hline & Cash + health & 0.234 & $0.229-0.238$ & 0.044 & $0.042-0.046$ & 0.125 & $0.121-0.130$ \\
\hline & Cash +3 non cash transfers & 0.212 & $0.208-0.217$ & 0.037 & $0.035-0.038$ & 0.104 & $0.100-0.108$ \\
\hline \multirow[t]{5}{*}{ Greece } & Cash only & 0.320 & $0.312-0.327$ & 0.088 & $0.083-0.092$ & 0.273 & $0.254-0.293$ \\
\hline & Cash + in kind rent subsidy & 0.320 & $0.312-0.327$ & 0.088 & $0.083-0.092$ & 0.273 & $0.254-0.293$ \\
\hline & Cash + education & 0.300 & $0.293-0.307$ & 0.076 & $0.073-0.080$ & 0.223 & $0.212-0.235$ \\
\hline & Cash + health & 0.285 & $0.278-0.292$ & 0.068 & $0.065-0.072$ & 0.204 & $0.193-0.214$ \\
\hline & Cash +3 non cash transfers & 0.267 & $0.261-0.274$ & 0.060 & $0.056-0.063$ & 0.174 & $0.165-0.182$ \\
\hline \multirow[t]{5}{*}{ Italy } & Cash only & 0.301 & $0.296-0.306$ & 0.079 & $0.076-0.082$ & 0.242 & $0.231-0.253$ \\
\hline & Cash + in kind rent subsidy & 0.301 & $0.296-0.306$ & 0.079 & $0.076-0.082$ & 0.242 & $0.231-0.252$ \\
\hline & Cash + education & 0.273 & $0.269-0.278$ & 0.065 & $0.062-0.068$ & 0.197 & $0.190-0.205$ \\
\hline & Cash + health & 0.266 & $0.261-0.271$ & 0.061 & $0.058-0.063$ & 0.183 & $0.177-0.190$ \\
\hline & Cash +3 non cash transfers & 0.241 & $0.236-0.245$ & 0.050 & $0.048-0.052$ & 0.151 & $0.146-0.157$ \\
\hline \multirow[t]{5}{*}{ UK } & Cash only & 0.318 & $0.313-0.322$ & 0.083 & $0.080-0.087$ & 0.241 & $0.222-0.260$ \\
\hline & Cash + in kind rent subsidy & 0.312 & $0.307-0.317$ & 0.081 & $0.077-0.084$ & 0.235 & $0.217-0.253$ \\
\hline & Cash + education & 0.293 & $0.288-0.297$ & 0.072 & $0.068-0.075$ & 0.199 & $0.192-0.205$ \\
\hline & Cash + health & 0.279 & $0.274-0.283$ & 0.065 & $0.062-0.068$ & 0.176 & $0.168-0.183$ \\
\hline & Cash +3 non cash transfers & 0.251 & $0.246-0.256$ & 0.054 & $0.051-0.057$ & 0.144 & $0.139-0.149$ \\
\hline
\end{tabular}

Source: EUROMOD

Notes: The 95\% confidence intervals shown were obtained with bootstrapping techniques using 1,000 replications. 
These results are driven by a number of factors. First, in-kind public housing tends to be allocated to those most in need which is often households on lower cash incomes. Second, since the main beneficiaries of public education services (children) and public health care services (elderly) are disproportionately located in the lower half of the income distribution, such transfers also reduce inequality. Third, since private education students who do not benefit from public education are far more likely to be found in richer households, such households experience a decline in their income share as we move from the monetary to the augmented income distribution. ${ }^{13}$ Nevertheless, it should be noted that even if all population members were receiving exactly the same transfers from the state, due to the scale invariance property of the inequality indices, ${ }^{14}$ measured inequality would decline.

Finally, we consider the effect of the inclusion of public transfers in kind in the concept of resources on the risk of poverty, as measured using the proportion of the population with equivalised income below 60 percent of the median. Table 8 contrasts the effect of using the standard cash measure of disposable income with that using income augmented by non cash transfers. The approach adopted is explicitly relative and the poverty threshold is recalculated for each income concept under analysis. It is worth noting that adding non cash income increases the median (and hence the threshold) by most in Belgium (31 percent), slightly less in Germany (30 percent), less in Italy and the UK (29 percent and 28 percent, respectively) and substantially less in Greece (22 percent). However, as clearly demonstrated in Table 8, the proportion of people below the relevant threshold is much lower in all countries, when using the augmented income measure. The effect is strongest in the UK where the "poverty" rate is reduced by more than a half and least strong in Greece where it is, nevertheless, reduced by a third. In all countries the reduction in the proportions of people in households with income below the thresholds is larger for children and older people. This is not surprising since the incidence of public spending for education and health care, respectively, is particularly concentrated on these two groups. The proportions of children below the threshold using the augmented measure are just a little over one quarter of those using the cash measure in Belgium and the UK and only one third of the elderly below the cash income threshold remain below the augmented income threshold in

${ }^{13}$ A similar argument can be made with respect to private health care insurance that may substitute public health care services.

${ }^{14}$.According to this principle the level of inequality remains unaffected by proportional changes in the incomes of the population members but declines as a result of equal additions to these incomes. If absolute inequality indices were used instead of relative ones, then inequality would have remained unaffected by equal additions to each individual's income (but at the cost of deriving different values of the inequality index every time we were using a different income metric. 
Table 8. Percentage of population groups with equivalised household disposable (cash) income and augmented (cash + non cash) income less than 60 percent of the median (poverty rates)

\begin{tabular}{lccccccr}
\hline Country & $\begin{array}{c}\text { Household } \\
\text { income concept }\end{array}$ & \multicolumn{2}{c}{$\begin{array}{c}\text { Overall } \\
\text { confidence } \\
\text { interval }\end{array}$} & $\begin{array}{c}\text { Children } \\
\text { confidence } \\
\text { interval }\end{array}$ & \multicolumn{2}{c}{$\begin{array}{r}\text { Elderly } \\
\text { confidence } \\
\text { interval }\end{array}$} \\
\hline Belgium & Cash & 10.3 & $9.4-11.2$ & 10.5 & $8.9-12.2$ & 19.0 & $16.7-21.3$ \\
& Cash + non cash & 5.4 & $4.8-6.0$ & 3.0 & $2.2-3.8$ & 6.2 & $4.8-7.7$ \\
\hline Germany & Cash & 13.0 & $12.1-13.9$ & 15.9 & $13.8-17.9$ & 16.0 & $14.0-18.0$ \\
& Cash + non cash & 6.9 & $6.2-7.5$ & 6.4 & $4.9-7.9$ & 5.5 & $4.4-6.6$ \\
\hline Greece & Cash & 18.9 & $17.8-20.0$ & 21.8 & $19.7-23.9$ & 25.1 & $23.1-27.2$ \\
& Cash + non cash & 12.7 & $11.7-13.7$ & 12.7 & $10.9-14.4$ & 15.1 & $13.3-16.9$ \\
\hline Italy & Cash & 17.6 & $16.9-18.2$ & 23.4 & $22.0-24.8$ & 16.4 & $15.3-17.5$ \\
& Cash + non cash & 11.1 & $10.6-11.6$ & 10.6 & $9.6-11.6$ & 7.7 & $7.0-8.3$ \\
\hline UK & Cash & 16.5 & $15.9-17.1$ & 19.5 & $18.4-20.6$ & 23.0 & $21.8-24.1$ \\
& Cash + non cash & 8.1 & $7.7-8.4$ & 5.2 & $4.7-5.7$ & 6.4 & $5.5-7.3$ \\
\hline
\end{tabular}

Source: EUROMOD

Notes: Incomes are equivalised using the modified OECD scale and median incomes are calculated across individuals using the income concept under analysis. Children are defined as persons aged 17 or below, elderly are defined as persons aged 65 or above. The $95 \%$ confidence intervals shown were obtained with bootstrapping techniques using 1,000 replications.

Belgium, Germany and the UK. As in the case of inequality, no statistically significant reranking of the countries is observed regarding their aggregate poverty rate when the public non cash incomes are included in the concept of resources. However, some re-ranking of countries is evident for the poverty risk of children and, particularly, the elderly.

However, it is doubtful whether these results should be interpreted as having bearing on the assessment of poverty or inequality from a welfare perspective. They are mainly of interest because they show the scale of non cash incomes relative to cash incomes, without taking into account the needs of individuals for health care or education. The next section attempts to address this issue. 


\section{Welfare interpretation and equivalence scales}

The practice adopted in the analysis so far is in line with most studies found in the relevant empirical literature, in the sense that the same equivalence scales are used to construct the distribution of augmented income as well as for the distribution of disposable income. This may be problematic, particularly in the case of public education and public health care where needs are characterized by strong life-cycle patterns. The reason is that the equivalence scales used to measure inequality in disposable income are "conditional" on the existence of free public education and free public health care (Pollak and Wales, 1979; Blundell and Lewbel, 1991). By introducing the latter in the concept of resources in the augmented income distribution, we treat them like private commodities that households must pay for in order to obtain them. Therefore, the equivalence scales should be modified accordingly.

This is not an easy task. Both education and health care have some rather unique characteristics. Their consumption is absolutely necessary for the individuals involved and it does not involve any economies of scale at the household level. Needs for education and health care are likely to vary far more with individual characteristics such as age rather than with income. At the limit, we can adopt a "fixed cost" approach, assuming that the needs of the recipients of these services are equal to a specific sum of money. For example, we could assume that the per capita amounts spent by the state for age-specific population groups on public education and public health care depict accurately the corresponding needs of these groups. Then, the re-calculation of equivalence scales is straightforward.

Assuming that $y$ is household disposable income, $k$ is the total amount of extra needs of the household members for health and education, $e$ the OECD scale and $e^{\prime}$ the new scale, the following should be valid for the household to remain in the same welfare level:

$$
\frac{y}{e}=\frac{y+k}{e^{\prime}}
$$

and $e^{\prime}$ should be equal to

$$
e^{\prime}=\frac{e(y+k)}{y}
$$

Naturally, there will be no single equivalence scale for households with identical composition - the scale will be higher (smaller economies of scale) in poorer households and lower (larger economies of scale) in better-off households. This is an old postulate of 
equivalence scales theory that was long abandoned in favour of simplicity and transparency (for comparative and policy purposes). ${ }^{15}$

In democratic societies $k$ and the size of the corresponding public provision is determined through various forms of negotiation at several levels. It is not cast in stone and may be affected by numerous factors such as the demographic composition of the population or short- versus long-term considerations. Therefore, there is room for sensitivity analysis, using alternative values of $k$ for specific services (education, health care) and population (age) groups.

As an illustration of the implications of this approach, in Table 9 we exploit cross-country spending variations in EU15 and adjust $k$ accordingly. In each country the value of $k$ used in the equivalence scales is adjusted in order to be equal as a share of GDP per capita to the EU15 unweighted average public spending for the corresponding educational level (primary, secondary, tertiary) and health care spending per age group (18 age groups). Therefore, for each household with $n$ members $(i=1, \ldots, n)$ with different characteristics (such as age) the needs for education and health care are assumed to be:

$$
k=\sum_{i=1}^{n}\left[k_{E N i} \frac{S_{E E U i}}{S_{E N i}}+k_{H N i} \frac{S_{H E U i}}{S_{H N i}}\right]
$$

where $k_{E N i}$ and $k_{H N i}$ are, respectively, national spending for public education and public health care for persons with characteristics $i, S_{E N i}$ and $S_{H N i}$ are national spending figures for public education and public health care expressed as a share of the country's GDP per capita (i.e. they are equal to $k_{E N i} / G D P_{p c N}$ and $k_{E H i} / G D P_{p c N}$, respectively) and $S_{E E U i}$ and $S_{H E U i}$ are the corresponding (unweighted) averages for EU15.16

Table 9 reports proportional changes in inequality indices when public education, health care and housing services are included in the concept of resources. Two alternative assumptions are used about which age groups have education needs. First (scenario 1), it is assumed that only people in age groups for whom education is compulsory have educational needs. School leaving age varies in the five countries under consideration: 14.5 in Greece, 15 in Italy, 16 in the UK, 18 in Belgium and Germany [OECD (2006), Table C1.2].

15 In case household disposable income is zero, $e^{\prime}$ cannot be uniquely determined and, hence, calculating equivalised augmented income not possible (where it is non-zero due to $k \neq 0$ ). Therefore, we have excluded such households from the sample for the following calculations. In each country, the share of such households was less than 0.5 percent.

16 The education expenditures are taken from OECD (2006) and the health expenditures from the OECD SOCX database. See Appendix tables A1 and A2 which show how national expenditures differ from the EU15 mean, by group (age and education level) as well as on average. 
Table 9. Proportional changes in inequality indices as a result of non cash public transfers in the fields of housing, education and health care using alternative equivalence scales

\begin{tabular}{|c|c|c|c|c|}
\hline Country & $\begin{array}{l}\text { Equivalence } \\
\text { scale }\end{array}$ & Gini & $\begin{array}{r}\text { Atkinson } \\
(0.5)\end{array}$ & $\begin{array}{r}\text { Atkinson } \\
(1.5)\end{array}$ \\
\hline \multirow[t]{3}{*}{ Belgium } & Baseline & -22.8 & -40.8 & -63.3 \\
\hline & Scenario 1 & $(-0.3)$ & -1.1 & $(-2.1)$ \\
\hline & Scenario 2 & 0.2 & 0.3 & $(-0.3)$ \\
\hline \multirow[t]{3}{*}{ Germany } & Baseline & -21.3 & -37.2 & -38.1 \\
\hline & Scenario 1 & -4.0 & -7.9 & -8.5 \\
\hline & Scenario 2 & -2.4 & -4.6 & -4.9 \\
\hline \multirow[t]{3}{*}{ Greece } & Baseline & -16.5 & -31.4 & -39.6 \\
\hline & Scenario 1 & 1.5 & 3.1 & 3.6 \\
\hline & Scenario 2 & 3.1 & 6.3 & 6.7 \\
\hline \multirow[t]{3}{*}{ Italy } & Baseline & -20.3 & -36.6 & -42.9 \\
\hline & Scenario 1 & -2.2 & -4.3 & -4.8 \\
\hline & Scenario 2 & -0.7 & -1.2 & -1.3 \\
\hline \multirow[t]{3}{*}{ UK } & Baseline & -21.0 & -35.3 & -41.3 \\
\hline & Scenario 1 & -2.0 & -3.9 & -7.6 \\
\hline & Scenario 2 & -1.1 & -2.1 & -2.3 \\
\hline
\end{tabular}

Source: EUROMOD

Notes: Changes in inequality are significantly different from zero at the $95 \%$ level except where the estimate is shown in brackets, i.e. for Belgium under scenario 1 (Gini and $\mathrm{A}(1.5)$ ) and scenario 2 (A(1.5)). Confidence intervals were obtained with bootstrapping techniques using 1,000 replications.

Scenario 1: only people in compulsory education age groups have education needs Scenario 2: all students have education needs

All people below these age thresholds and above the compulsory primary education enrolment age are considered to have educational needs (including those who do not receive any public transfers like private education students), while the rest of the students in noncompulsory stages of the education system may receive public transfers but are assumed not to have the corresponding needs. Scenario 2 assumes that all students have needs for education services, irrespective of their educational level. 
The first row in each country panel of the table ("Baseline") reports the proportional changes of the inequality indices between the estimates derived from the distribution of disposable income and the same distribution augmented by the value of in kind public education, health care and housing services using the modified OECD scales, as shown in Table 7. The impact of the transfers appears to be very large. In the next two lines, the distribution of equivalised income is derived using the equivalence scales in (2) and the proportional changes from the baseline distribution (distribution of equivalised disposable income using the modified OECD equivalence scales) are reported. This time, the changes appear to be modest, although statistically significant (except some indicators for Belgium). They are inequality-reducing in most cases, except in Greece. In the first scenario the decline is due to the transfers to households with members in the non-compulsory stages of education (who are assumed to receive transfers in kind without having corresponding needs), to the needs of private education students (who are not receiving public transfers), to the effects of public housing subsidies and to differences in the national levels of spending on health and education (included in income) and those at the EU average (providing our illustrative measure of needs). These factors are on balance inequality-reducing especially in Germany but also in Italy and the UK, and particularly when using inequality indices sensitive to changes close to the bottom of the distribution, such as Atkinson (1.5). In the second scenario all students and people of compulsory school age are considered to have education needs. In this case the net effect on inequality is negligible in most cases, with small but significant reductions remaining in Germany, Belgium and the UK. In Greece, on the other hand, the increase in inequality becomes larger in scenario 2 than in scenario 1 . If alternative values of $k$ are employed, for example by taking the EU minimum or maximum shares of spending for public education and health care as the yardstick with which to measure needs, then the net effects on inequality is scaled accordingly. Lower values attributed to needs result in larger net reductions in inequality than those shown in Table 9. This is due to lower new equivalence scales for households with education or health transfers and, hence, higher equivalised augmented incomes. Given the location of such households in the income distribution, the overall result is then a further decrease in income inequality. Higher values result in smaller reductions or, indeed, increases in inequality.

We believe that the approach outlined above can contribute to a better understanding of the distributional effects of non cash public transfers. At this stage it may still be relatively crude but can be improved in several ways. The two most promising avenues are likely to be in the direction of uncovering variations in the quality of services directed to particular segments 
of the population and the identification of systematic under- or over- users of such services. For example, in countries with federal rather than national education or health systems it may be possible to identify regions with higher spending per capita (provided there is evidence that the higher spending is translated in higher quality of services). In the case of education we can identify people who do not use public services and we can bring preprimary education into the picture. In the case of health care we can differentiate between males and females, identify private health insurance holders who may systematically underuse the public health care system or groups that make excessive use of public services (Le Grand and Winter, 1985). Likewise, we can also identify people with disabilities or chronic illness whose needs are likely to be higher than the rest of the population. Finally, $k$ may be made to vary with $y$, albeit less slowly than the conventional equivalence scales assume.

\section{Conclusions}

Standard microeconomic theory suggests that cash transfers are superior to non cash transfers, since using cash transfers individuals may be able to allocate their budgets to commodities freely, so as to maximize their welfare. However, there are many theoretical arguments in favor of transfers in kind (Thurow (1974), Nelson (1987), Currie and Gahvari (2008)), in practice governments use them extensively and, as Knetsch (1995) points out, in many circumstances people seem to prefer non cash to cash transfers of equal value. Non cash benefits in the form of publicly provided education, health and housing subsidies together make up an important supplement to cash incomes in Europe, and in particular in the five countries that we consider. Nevertheless even in combination they are smaller in size, on average, than cash benefits.

Non cash benefits add a larger proportion to the resources available to households with low disposable incomes than they do to households with high income. Their absolute size also tends to be larger for households with low cash incomes. To the extent that the size and incidence of these non cash incomes differ across countries it is important that they are accounted for - or considered in some way - in cross-national comparisons of income inequality and poverty. Among the countries we consider the differences in size and distributional effect are small, relative to those we would observe if we compared EU countries with the US or other developed countries outside Europe. However, there are important differences, which can be summarised as follows. Firstly, public housing subsidies, while relatively small in magnitude and almost non-existent in some countries, nonetheless add 1 percent to cash disposable incomes as a whole in the UK and somewhat 
less than this in Germany. The aggregate effect of public education ranges from 6 percent of disposable income in Greece and Germany to 10 percent in Belgium and for health the range is between 12 percent in Greece and 17 percent in Belgium and Germany. Given the differences in scale of spending, the distributional effect is quite similar in all five countries, but with education having a somewhat more pronounced effect on inequality measures in Italy than in other countries, and public health care having a larger effect in Belgium.

Comparisons with the US would be very interesting. The evidence in Marical et al. (2006) suggests that US public expenditure for non cash transfers as a share of GDP is lower than in all countries considered here, apart from Greece. Moreover, the ratio of non cash to cash public transfers is substantially higher in the US than in any of the countries included in our analysis, reflecting the relatively more limited role of public cash transfers in the US. At the same time, the share of private health expenditure is substantially higher in the US than in the EU and the role of social housing is quite limited. Nevertheless, both health care and social housing seem to be better targeted towards the poor in the US than in EU countries (this is particularly so in the case of the elderly; see Smeeding, 1986). Using simpler techniques than those employed in this paper, Marical et al. (2006) conclude that even though non cash transfers reduce inequality more in the US than in Europe, their inclusion in the concept of resources still leaves the US at a level of inequality higher than that of almost all EU countries (see, also, Garfinkel et al, 2006).

Two further points remain. First, it is doubtful whether results derived using the standard approach in the field of static incidence analysis can have a straightforward welfare interpretation. Using this approach we incorporate the value of the public services in the concept of household resources but ignore the problem of extra needs of public services recipients. Once these needs are taken into account with appropriate changes in the household equivalence scales used in the analysis, the distributional effects of non cash transfers appear to be far more modest and, under particular circumstances may even appear to increase inequality.

Secondly, the practical lessons from this comparative empirical exercise should not be forgotten. The results presented in this paper are as comparable as possible but there are nevertheless some factors that may apply in different ways across countries and these should not only be borne in mind but also provide the basis for future improvements in data and methods for the type of exercise we have carried out. Publicly provided education, health care and housing are organised differently across countries and common analytical 
choices - for example in the inclusion or otherwise of pre-primary education or tertiary students living on their own - have different implications across countries. Furthermore, the available comparable data on spending by sub-group (e.g. pupils by sub-level of education or healthcare by gender) may be insufficient to capture differential levels of spending that may be important in some countries but not in others. Micro-data from income surveys may not carry enough information about the use of private alternatives to public services (or copayments) for the private components of spending to be captured properly. Again, the importance of these will vary with national context. While we believe that we have made a contribution to the comparative evidence on the distributional effects of non cash benefits, many challenges remain. 


\section{References}

Aaberge, R. \& Langørgen, A. (2006). Measuring the Benefits from Public Services: The Effects of Local Government Spending on the Distribution of Income in Norway. Review of Income and Wealth, 52 (1), 61-83.

Afonso, A. \& St. Aubyn, M. (2005). Non-parametric approaches to education and health efficiency in OECD countries. Journal of Applied Economics 8(2), 227-246.

Afonso, A., Schuknecht, L. \& Tanzi, V. (2005). Public sector efficiency: An international comparison. Public Choice, 123, 321-347.

Antoninis, M. \& Tsakloglou, P. (2001). Who benefits from public education in Greece? Evidence and policy implications. Education Economics 9, 197-222.

Berloffa, G., Brugiavini, A. \& Rizzi, D. (2006). Health, Welfare and Inequality. University Ca' Foscari of Venice, Dept. of Economics Research Paper Series No. 41/06.

Blundell, R. \& Lewbel, A. (1991). The information content of equivalence scales, Journal of Econometrics, 50, 49-68.

Borsch-Supan, A. \& Reil-Held, A. (2001). How Much is Transfer and How Much is Insurance in a Pay-as-you-go System? The German Case. Scandinavian Journal of Economics, $103,505-524$.

Callan, T., Smeeding, T. \& Tsakloglou, P. (2007). Distributional effects of public education transfers in seven European countries AIM-AP report, http://www.iser.essex.ac.uk/files/msu/emod/aim-ap/deliverables/AIMAP1.2.pdf

Carone, G., Costello, D., Diez Guardia, N., Mourre, G., Przywara, B. \& Salomaki, A. (2005). The economic impact of ageing populations in the EU25 Member States. European Economy 236.

Caussat, L., Le Minez, S. \& Raynaud, D. (2005). L'assurance-maladie contribue-t-elle à redistribuer les revenus? Drees, Dossiers solidarité et santé - Études sur les dépenses de santé, La Documentation Francaise, Paris.

Costello, D. \& Bains, M. (2001), Budgetary challenges posed by ageing populations. Directorate General for Economic and Financial Affairs of the European Commission, Economic Policy Committee Document EPC/ECFIN/655/01-EN final.

Currie, J. \& Gahvari, F. (2008). Transfers in Cash and In-Kind: Theory Meets the Data, Journal of Economic Literature, 46(2), 333-383.

Esping-Andersen, G. (1990). The three worlds of welfare capitalism. New Jersey: Princeton University Press.

Evandrou, M., Falkingham, J., Hills, J. \& Le Grand, J. (1993). Welfare benefits in kind and income distribution. Fiscal Studies, 14 (1), 57-76.

Ferrera, M. (1996). The 'Southern model' of welfare in Social Europe. Journal of European Social Policy, 6, 17-37.

Frick, J. R. \& Grabka, M. M. (2003). Imputed Rent and Income Inequality: A Decomposition Analysis for the U.K., West Germany, and the USA. Review of Income and Wealth, 49(4), 513-537. 
Frick, J.R., Grabka, M.M, Smeeding, T.M. \& Tsakloglou, P. (2008). Distributional effects of imputed rents in seven European countries. AIM-AP report http://www.iser.essex.ac.uk/files/msu/emod/aim-ap/deliverables/AIM-AP1.1.pdf

Garfinkel, I., Rainwater, L., \& Smeeding, T.M. (2006). A Reexamination of Welfare State and Inequality in Rich Nations: How In-Kind Transfers and Indirect Taxes Change the Story. Journal of Policy Analysis and Management, 25, 855-919.

Harding, A., Lloyd, R. \& Warren, N. (2006). Moving beyond traditional cash measures of economic well-being: including indirect benefits and indirect taxes. National Centre for Social and Economic Modelling, Discussion Paper no. 61, University of Canberra.

Hernández-Quevado, C., Jones, A.M., López-Nicolás, A. \& Rice, N. (2006). Socio-economic inequalities in health: A comparative longitudinal analysis using the European Community Household Panel. Social Science \& Medicine, 63(5).

Hugounenq, R. (1998). Les Consommations publiques et la redistribution: Le Cas de l'éducation. Document de travail, Conseil de l'emploi, des revenus et de la cohésion sociale (CERC), Paris.

James, E. \& Benjamin, G. (1987). Educational distribution and income redistribution through education in Japan. Journal of Human Resources, 22, 469-489.

Jones, A. \& O'Donnell, O. (1995). Equivalence scales and the costs of disability. Journal of Public Economics, 56, 273-289.

Jones, F., Annan, D. \& Shah, S. (2008). The redistribution of household income, 1997 to 2006/7. Economic and Labour Market Review 2(12), Office of National Statistics, London.

Klavus, J. (1999). Health care and economic well-being: Estimating equivalence scales for public health care utilization. Health Economics, 8, 613-625.

Knetsch, J.L. (1995). Assumptions, behavioural findings and policy analysis. Journal of Policy Analysis and Management, 14(1), 68-78.

Lampman, R.J. (1984). Social Welfare Spending. New York: Academic Press.

Le Grand, J. \& Winter, D. (1985). The middle classes and the welfare state under Conservative and Labour governments. Journal of Public Policy, 6, 399-430.

Lietz, C. \& Mantovani, D. (2007). A Short Introduction to EUROMOD: An Integrated European Tax-Benefit Model. In O. Bargain (Ed.), Micro-simulation in action: Policy analysis in Europe using EUROMOD. Research in Labor Economics, Vol. 25. Elsevier.

Marical, F., Mira d'Ercole, M., Vaalavuo, M. \& Verbist, G. (2006). Publicly-provided Services and the Distribution of Resources. OECD Social, Employment and Migration Working Paper No. 45, OECD, Paris.

McLennan, W. (1996). The Effects of Government Benefits and Taxes on Household Income: 1993-94 Household Expenditure Survey Australia. Australian Bureau of Statistics Report No. 6537.0

Nelson, R.R. (1987). Roles of Government in a Mixed Economy. Journal of Policy Analysis and Management, 6(4), 541-557.

O'Higgins, M. \& Ruggles, P. (1981). The distribution of public expenditures and taxes among households in the United Kingdom. Review of Income and Wealth, 27(3). 
OECD, (2006). Education at a glance 2006. Paris: OECD.

Pollak, R. \& Wales, T. (1979). Welfare comparisons and equivalence scales. American Economic Review, 69 (Papers and Proceedings), 216-221.

Radner, D.B. (1997). Noncash income, equivalence scales and the measurement of economic well-being. Review of Income and Wealth 43, 71-88.

Rochet, J.C. (1991). Incentives, Redistribution and Welfare State. Geneva Papers of Risk and Social Insurance, 16, 143-165.

Sefton, T. (2002). Recent Changes in the Distribution of the Social Wage,.CASE Paper No 62, Centre for Analysis of Social Exclusion, LSE.

Smeeding, T.M. (1982). Alternative Methods for Valuing Selected In-Kind Transfer Benefits and Measuring Their Effect on Poverty. U.S. Bureau of Census Technical Paper No. 50. Washington, DC: U.S. Government Printing Office.

Smeeding, T.M. (1986). Nonmoney Income and the Elderly: The Case of the 'Tweeners'. Journal of Policy Analysis and Management, 5(4), 707-724.

Smeeding, T.M., Saunders, P., Coder, J., Jenkins, S.P., Fritzell, J. Hagenaars, A.J.M. Hauser, R. \& Wolfson, M. (1993). Poverty, inequality and living standard impacts across seven nations: the effects of non-cash subsidies for health, education and housing. Review of Income and Wealth, 39, 229-256.

Smeeding, T.M., Tsakloglou, P. \& Verbist, G. (2008). Distributional effects of public health care transfers in seven European countries. AIM-AP report www.iser.essex.ac.uk/files/msu/emod/aim-ap/deliverables/AIM-AP1.3.pdf

Steckmest, E. (1996). Noncash benefits and income distribution. LIS Working Paper No. 100, Luxembourg.

Sutherland, H. (2007). EUROMOD: the tax-benefit microsimulation model for the European Union. In A. Gupta \& A. Harding (Eds.), Modelling Our Future: population ageing, health and aged care, International Symposia in Economic Theory and Econometrics Vol 16, Elsevier 483-488.

Ter Rele, H. (2007). Measuring the lifetime redistribution achieved by Dutch taxation, cash transfer and non-cash benefit programs. Review of Income and Wealth, 53, 335-362.

Thurow, L.C. (1974). Cash versus in-kind transfers. American Economic Review, 64(2) (Papers and Proceedings), 190-195.

Tsakloglou, P. \& Antoninis, M. (1999). On the distributional impact of public education: evidence from Greece. Economics of Education Review, 18, 439-452.

Wagstaff, A., van Doorslaer, E., van der Burg, H., Calonge, S., Christiansen, T., Citoni, G., Gerdtham, U.-G., Gerfin, M., Geurts, J., Gross, L., Hakinnen, U., Johnson, P., Klavus, J., Lachaud, C., Lauritsen, J., Leu, R., Nolan, B., Perano, E., Pereira, J., Propper, C., Puffer, F., Rochaix, L., Rodriguez, M., Schellhorn, M., Sundberg, G. \& Winkelhake, O. (1999). Equity in the finance of health care: some further international comparisons. Journal of Health Economics, 18, 263-290

Whiteford, P. \& Kennedy, S. (1995). Incomes and living standards of older people. Department of Social Security Research Report No 43, HMSO, London. 
Willner, J. \& Parker ,D. (2007). The Performance of Public and Private Enterprise under Conditions of Active and Passive Ownership and Competition and Monopoly. Journal of Economics, 90(3), 221-253.

Wolff, E. \& Zacharias, A. (2006). An overall assessment of the distributional consequences of government spending and taxation in the United States, 1989 and 2000. In D. Papadimitriou (Ed.), The Distributional Effects of Government Spending and Taxation, New York: Palgrave/Macmillan, 15-68.

Zaidi, A. \& Burchardt, T. (2005). Comparing incomes when needs differ: Equivalization for the extra costs of disability in the UK. Review of Income and Wealth, 51 89-114. 


\section{APPENDIX}

Table A1 Difference between national and EU15 mean education spending, by level of education (in percent of GDP/capita)

\begin{tabular}{|c|c|c|c|c|c|c|c|c|c|c|c|}
\hline \multirow[b]{2}{*}{$\begin{array}{l}\text { Education } \\
\text { level }\end{array}$} & \multicolumn{6}{|c|}{ National and EU15 mean levels of spending } & \multicolumn{5}{|c|}{ Difference (EU15 - national) } \\
\hline & Belgium & Germany & Greece & Italy & UK & $\begin{array}{r}\text { EU-15 } \\
\text { mean } \\
\end{array}$ & Belgium & Germany & Greece & Italy & UK \\
\hline Primary & 21 & 17 & 21 & 28 & 20 & 21 & -0.1 & 3.9 & -0.1 & -7.1 & 0.9 \\
\hline secondary & 26 & 26 & 24 & 30 & 25 & 27 & 0.8 & 0.8 & 2.8 & -3.2 & 1.8 \\
\hline Tertiary & 27 & 26 & 18 & 21 & 31 & 27 & -0.2 & 0.8 & 8.8 & 5.8 & -4.2 \\
\hline
\end{tabular}

Table A2. Difference between national and EU15 mean healthcare spending, by age group (in percent of GDP/capita)

\begin{tabular}{|c|c|c|c|c|c|c|c|c|c|c|c|}
\hline \multirow[b]{2}{*}{$\begin{array}{l}\text { Age } \\
\text { group }\end{array}$} & \multicolumn{6}{|c|}{ National and EU15 mean levels of spending } & \multicolumn{5}{|c|}{ Difference (EU15 - national) } \\
\hline & Belgium & Germany & Greece & Italy & UK & $\begin{array}{r}\text { EU-15 } \\
\text { mean } \\
\end{array}$ & Belgium & Germany & Greece & Italy & UK \\
\hline $0-4$ & 3.9 & 5.1 & 3.0 & 4.1 & 4.3 & 4.1 & 0.2 & -1.0 & 1.1 & 0.0 & -0.2 \\
\hline $5-9$ & 2.6 & 3.4 & 2.0 & 2.7 & 2.8 & 2.7 & 0.1 & -0.7 & 0.7 & 0.0 & -0.1 \\
\hline $10-14$ & 2.3 & 3.0 & 1.8 & 2.4 & 2.5 & 2.4 & 0.1 & -0.6 & 0.6 & 0.0 & -0.1 \\
\hline $15-19$ & 2.4 & 3.2 & 1.9 & 2.5 & 2.7 & 2.6 & 0.2 & -0.6 & 0.7 & 0.1 & -0.1 \\
\hline $20-24$ & 2.8 & 3.7 & 2.2 & 2.9 & 3.0 & 2.9 & 0.1 & -0.8 & 0.7 & 0.0 & -0.1 \\
\hline $25-29$ & 3.1 & 4.1 & 2.4 & 3.2 & 3.4 & 3.3 & 0.2 & -0.8 & 0.9 & 0.1 & -0.1 \\
\hline $30-34$ & 3.4 & 4.4 & 2.6 & 3.5 & 3.7 & 3.6 & 0.2 & -0.8 & 1.0 & 0.1 & -0.1 \\
\hline $35-39$ & 3.7 & 4.7 & 2.8 & 3.7 & 4.0 & 3.8 & 0.1 & -0.9 & 1.0 & 0.1 & -0.2 \\
\hline $40-44$ & 3.9 & 5.0 & 2.9 & 3.9 & 4.2 & 4.0 & 0.1 & -1.0 & 1.1 & 0.1 & -0.2 \\
\hline $45-49$ & 4.3 & 5.5 & 3.2 & 4.3 & 4.6 & 4.4 & 0.1 & -1.1 & 1.2 & 0.1 & -0.2 \\
\hline $50-54$ & 4.9 & 6.3 & 3.6 & 5.0 & 5.3 & 5.1 & 0.2 & -1.2 & 1.5 & 0.1 & -0.2 \\
\hline $55-59$ & 5.9 & 7.7 & 4.4 & 6.0 & 6.3 & 6.1 & 0.2 & -1.6 & 1.7 & 0.1 & -0.2 \\
\hline $60-64$ & 7.4 & 9.5 & 5.6 & 7.5 & 7.9 & 7.7 & 0.3 & -1.8 & 2.1 & 0.2 & -0.2 \\
\hline $65-69$ & 9.3 & 11.9 & 7.1 & 9.4 & 9.8 & 9.7 & 0.4 & -2.2 & 2.6 & 0.3 & -0.1 \\
\hline $70-74$ & 11.5 & 14.8 & 8.8 & 11.7 & 12.2 & 12.0 & 0.5 & -2.8 & 3.2 & 0.3 & -0.2 \\
\hline 75-79 & 14.1 & 17.8 & 10.8 & 14.1 & 14.7 & 14.5 & 0.4 & -3.3 & 3.7 & 0.4 & -0.2 \\
\hline $80-84$ & 16.7 & 21.0 & 12.8 & 16.7 & 17.2 & 17.1 & 0.4 & -3.9 & 4.3 & 0.4 & -0.1 \\
\hline $85-89$ & 15.8 & 20.6 & 12.3 & 16.0 & 16.8 & 16.5 & 0.7 & -4.1 & 4.2 & 0.5 & -0.3 \\
\hline $90-94$ & 15.0 & 19.1 & 12.2 & 15.2 & 16.4 & 16.0 & 1.0 & -3.1 & 3.8 & 0.8 & -0.4 \\
\hline $95+$ & 14.1 & 17.0 & 11.6 & 15.0 & 15.0 & 16.3 & 2.2 & -0.7 & 4.7 & 1.3 & 1.3 \\
\hline
\end{tabular}

